\title{
LITERATURE REVIEW: HUBUNGAN PENGETAHUAN TERHADAP SIKAP MASYARAKAT TENTANG UPAYA PENCEGAHAN PENULARAN TUBERCULOSIS
}

\author{
Literature Review: Relationship Of Knowledge To Community Attitude About \\ Tuberculosis Prevention Measures
}

\author{
Fitriani Ningsih ${ }^{*}$ \\ Riska Ovany ${ }^{2}$ \\ Yuni Anjelina ${ }^{3}$ \\ 123 Prodi Kesehatan Masyarakat, \\ STIKES Eka Harap, Palangka \\ Raya, Kalimantan Tengah, \\ Indonesia
}

*email:feghanz@gmail.com

\begin{abstract}
Abstrak
Tuberkulosis (TB) merupakan salah satu penyakit infeksi menular, yang disebabkan oleh kuman Mycobacterium Tuberculosis. Tuberkulosis saat ini masih merupakan masalah kesehatan masyarakat dunia yang menjadi tantangan global. Salah satu penyebab kurangnya pengetahuan masyarakat dalam upaya pencegahan penularan penyakit Tuberculosis adalah kurangnya informasi serta edukasi dari tenaga kesehatan atau kader-kader posyandu tentang Tuberculosis sehingga menyebabkan kurangnya pengetahuan masyarakat mengenai penyakit Tuberculosis. Penelitian ini bertujuan Untuk menjelaskan "Hubungan Tingkat Pengetahuan Dengan Sikap Masyarakat Tentang Upaya Pencegahan Penularan Tuberculosis Paru” berdasarkan data melalui metode Literature Riview. Menggunakan metode Literature Riview. Penelusuran jurnal menggunakan database akademik yaitu Google Scholar yang publikasi pada tahun 2017-2020 menggunakan Bahasa Indonesia dan Bahasa Inggris. Desain penelitian Cross-sectional. Dari ke 6 jurnal tersebut, terdapat 3 jurnal yang menyatakan terdapat hubungan antara pengetahuan dengan sikap masyarakat tentang upaya pencegahan penularan Tuberculosis dengan nilai $p$ value $=0,05$ ) sedangkan 3 jurnal menyatakan tidak ada hubungan antara pengetahuan dengan upaya pencegahan Tuberculosis tetapi terdapat hubungan antara sikap dengan upaya pencegahan Tuberculosi. Salah satu penyebab kurangnya pengetahuan masyarakat dalam upaya pencegahan penularan penyakit Tuberculosis adalah kurangnya informasi serta edukasi dari tenaga kesehatan atau kader-kader posyandu tentang Tuberculosis sehingga menyebabkan kurangnya pengetahuan masyarakat mengenai penyakit Tuberculosis. Faktor lain yang dapat mempengaruhi Sikap seseorang seperti keluarga, pengaruh teman sebaya, pengalaman pribadi, dan informasi yang diperoleh dari berbagai sumber.
\end{abstract}

Kata Kunci:

Kata Kunci:

Tuberculosis

Pengetahuan

Sikap

\section{Keywords: \\ Tuberculosis \\ Knowledge \\ Attitude}

\begin{abstract}
Tuberculosis is an infectious disease caused by the bacteria Mycobacterium tuberculosis. Tuberculosis is still a global public health problem that is a global challenge. One of the causes of the lack of public knowledge in efforts to prevent the transmission of Tuberculosis is the lack of information and education from health workers cadres about Tuberculosis, resulting in a lack of public knowledge about Tuberculosis. This study aims to explain " Corelation Between Knowledge Level And Attitude Of The Community About The Prevention Of Transmission Of Lung Tuberculosis" based on data through the Literature Review method. Using the Literature Review method. Journal searches use an academic database, namely Google Scholar which was published in 2017-2020 using Indonesian and English. Cross-sectional study design. Of the 6 journals, there are 3 journals which state that there is a relationship between knowledge and public attitudes about efforts to prevent Tuberculosis transmission with $p$ value $=0.05$ ). while 3 journals state that there is no relationship between knowledge and efforts to prevent Tuberculosis but there is a relationship between attitudes and Tuberculosis prevention efforts. One of the causes of the lack of public knowledge in efforts to prevent the transmission of Tuberculosis is the lack of information and education from health workers or posyandu cadres about Tuberculosis, causing a lack of public knowledge about Tuberculosis. Other factors that can influence a person's attitude such as family, influence of friends, personal experience, and information obtained from various source
\end{abstract}




\section{PENDAHULUAN}

Tuberkulosis (TB) merupakan salah satu penyakit infeksi menular, yang disebabkan oleh kuman Mycobacterium Tuberculosis. Tuberkulosis saat ini masih merupakan masalah kesehatan masyarakat dunia yang menjadi tantangan global (Direktorat Jenderal Pengendalian Penyakit dan Petunjuk Penyehatan Lingkungan, 2017). Salah satu penyebab kurangnya pengetahuan masyarakat dalam upaya pencegahan penularan penyakit Tuberculosis adalah kurangnya informasi serta edukasi dari tenaga kesehatan atau kader-kader posyandu tentang Tuberculosis sehingga menyebabkan kurangnya pengetahuan masyarakat mengenai penyakit Tuberculosi, Serta rendahnya kunjungan masyarakat ke Posyandu dan Puskesmas untuk memeriksakan diri atau deteksi dini terkait penyakit Tuberculosis. Selain itu faktor pengetahuan dan sikap mempunyai pengaruh besar terhadap status kesehatan individu maupun masyarakat dan berperan penting dalam menentukan keberhasilan suatu program penanggulangan penyakit dan pencegahan penularannya termasuk penyakit Tuberkulosis. Dalam hal ini Pengetahuan masyarakat mengenai gejala penyakit Tuberkulosis relatif cukup baik akan tetapi sikap masyarakat masih kurang peduli terhadap akibat yang dapat ditimbulkan oleh penyakit Tuberkulosis. Sikap masyarakat yang tidak peduli dengan akibat yang ditimbulkan oleh penularan penyakit Tuberculosis seperti belum membudayakan perilaku hidup bersih dan sehat (mencuci tangan dengan air bersih dan menggunakan sabun), masyarakat belum menerapkan pengobatan secara taratur/rutin, tidak rutin minum obat sesuai dengan yang di anjurkan oleh tenaga kesehatan serta belum menerapkan etika pola batuk yang benar dan tidak mau memeriksakan dahak dengan alasan mereka malu dan takut divonis menderita Tuberculosis sehingga sikap masyarakat yang seperti ini lah yang mempengaruhi status derajat kesehatan dimasyarakat tersebut.

Global Tuberculosis Report WHO (2017), Angka insiden Tuberkulosis di Indonesia 39I per 100.000 penduduk dan angka kematian 42 per 100.000 penduduk sedangkan menurut pemodelan yang berdasarkan data hasil survei prevalensi Tuberkulosis pada tahun 2017 sebesar 619 per 100.000 sedangkan pada tahun 2016 sebesar 628 per 100.000 (Direktorat Jenderal Pengendalian Penyakit dan Petunjuk Penyehatan Lingkungan, 2017). Prevalensi Tuberkulosis tahun 20132014, Prevalensi Tuberkulosis dengan konfirmasi bakteriologis di indonesia sebasar 759 per 100.000 penduduk berumur 15 tahun ke atas dan prevalensi Tuberkulosis BTA positif sebesar 257 per 100.000 penduduk berumur 15 tahun keatas (Direktorat Jenderal Pengendalian Penyakit dan Petunjuk Penyehatan Lingkungan, 2017). Di Provinsi Kalimantan Tengah kasus TBC masih cukup tinggi pada tahun 2018 kasus TBC yang ternotifikasi 3.679 kasus (5,08\%), Pada tahun 2019 kasus TBC ternotifikasi 3.833 kasus (8,34\%) dan pada tahun 2020 kasus TBC ternotifikasi 2.085 kasus(7,96\%). Pada tahun 2018 kasus TBC yang ternotifikasi ada 187 kasus per 100.000 penduduk di kota Palangka Raya. Sedangkan tahun 2019 kasus TBC yang ternotifikasi ada 320 kasus per- 100.000 penduduk, mengalami peningkatan jika di bandingkan pada tahun 2018. Dan pada tahun 2020 ada ternotifikasi 166 kasus di Kota Palangka Raya per100.000 penduduk, mengalami penurunan jika dibandingkan pada tahun 2019 (Dinas Kesehatan Kota Palangkaraya, 2020). Permenkes Nomor 67 Tahun 2016 tentang Penanggulangan Tuberkulosis menetapkan target program Penanggulangan TBC nasional yaitu eliminasi pada tahun 2035 dan Indonesia Bebas TBC Tahun 2050. Eliminasi TBC adalah tercapainya jumlah kasus TBC I per 1.000 .000 penduduk (Indah, 2020). Sementara pada tahun 2020 diketahui jumlah kasus Tuberculosis sebesar 166 per 1.00 .000 penduduk atau 16,60 per 1.000 .000 penduduk, sehingga dapat diketahui bahwa kasus Tuberculosis di Kota Palangka Raya masih belum memenuhi target nasional yaitu jumlah kasus Tuberculosis I per 1.000.000 penduduk. 
Faktor pengetahuan dan sikap mempunyai pengaruh besar terhadap status kesehatan individu maupun masyarakat dan berperan penting dalam menentukan keberhasilan suatu program penanggulangan penyakit dan pencegahan penularannya termasuk penyakit Tuberkulosis. Menurut hasil penelitian Simak bahwa masyarakat yang memiliki pengetahuan yang rendah mempunyai risiko tertular Tuberkulosis sebesar 2,5 kali lebih banyak dari orang yang berpengetahuan tinggi. Meningkatnya jumlah penderita TB Paru di Indonesia disebabkan oleh perilaku yang tidak sehat. Menurut Ditjen Pemberantas Penyakit Menular dan Penyehatan Lingkungan (20l4), tingginya angka kejadian TB Paru disebabkan kurangnya pengetahuan masyarakat Indonesia tentang TB Paru. Hanya 8\% responden yang menjawab dengan betul cara penularan TB $66 \%$ yang mengetahui tanda dan gejala (Departemen Kesehatan RI, 20I4). Penelitian terdahulu didapatkan pengetahuan masyarakat mengenai gejala penyakit Tuberkulosis relatif cukup baik akan tetapi sikap masyarakat masih kurang peduli terhadap akibat yang dapat ditimbulkan oleh penyakit Tuberkulosis sehingga membuat perilaku dan kesadaran masyarakat untuk memeriksakan dahak sebagai salah satu upaya pencegahan penyakit Tuberkulosis masih kurang dengan alasan mereka malu dan takut di vonis menderita Tuberkulosis (Samingan, 2017). Menurut hasil penelitian yang dilakukan oleh Ramdhani, \& Purba (2016) yang menyatakan bahwa responden dengan pengetahuan yang tinggi memiliki tindakan pencegahan TB Paru lebih baik dibandingkan responden dengan pengetahuan yang rendah begitupun dengan sikap akan mudah terbentuk apabila situasi melibatkan faktor emosional, serta pengaruh kebudayaan dan media massa yang menyampaikan informasi (Ridwan, 2019). Penelitian yang sama juga di lakukan oleh Penelitian terkait juga disampaikan oleh Rahman, dkk (2017) yang menyatakan ada hubungan yang signifikan antara tingkat pengetahuan TB Paru

Tabel I. Rangkuman Hasil Literatur Review dengan upaya pencegahan TB Paru di wilayah kerja Puskesmas Bawahan Selan Kabupaten Banjar. Dampak dari TB Paru adalah kehilangan nafsu makan dan mengalami penurunan berat badan yang disertai dengan demam, keringat malam hari, dan kelelahan dan yang lebih parah dapat menyebabkan kerusakan pada jantung, ginjal, kerusakan fungsi hati, kerusakan pada tulang dan sendi, menyerang cincin tulang belakang dan selaput sekeliling otak, serta gangguan fungsi penglihatan (Direktorat Jenderal Pengendalian Penyakit dan Petunjuk Penyehatan Lingkungan, 2017).

\section{METODOLOGI}

\section{Jenis Penelitian}

Metode Penelitian yang digunakan dalam penelitian ini adalah literatur review. literatur review adalah analisis terintegrasi tulisan ilmiah yang terkait langsung dengan pertanyaan penelitian. Strategi yang digunakan untuk mencari literatur dalam penelitin ini adalah menggunakan PICOS (Population, Intervensie, Comparison, Outcome, Study Design) dengan kriteria inklusi dan eksklusi.

\section{Metode Analisis Data}

Metode analisis literatur dalam penelitian ini menggunakan metode analisis deskriftif yaitu menyajikan data dan menjabarkan secara naratif hasilhasil penelitian yang didapatkan dari artikel yang dijadikan sebagai sumber literatur.

\section{HASIL DAN PEMBAHASAN}

\section{HASIL}

Artikel penelitian yang berhasil didapatkan dalam penelitian ini berasal dari Negara Indonesia. 6 artikel yang didapatkan semuanya menggunakan teknik pengumpulan data dengan cara kuisioner dan wawancara dengan memberikan lembar pertanyaan. 


\begin{tabular}{cccccc}
\hline No & $\begin{array}{c}\text { Nama Peneliti } \\
\text { dan Tahun }\end{array}$ & $\begin{array}{c}\text { Negara/ } \\
\text { Tempat }\end{array}$ & $\begin{array}{c}\text { Design } \\
\text { Penelitian }\end{array}$ & $\begin{array}{c}\text { Responden } \\
\text { Penelitian }\end{array}$ & Hasil Temuan Penelitian \\
\hline I. & Offi Miranda et & Indonesia & Cross Sectional. & 87 responden & Berdasarkan hasil penelitian dapat di lihat
\end{tabular}
al, 2019.

sebagian besar masyarakat memiliki tingkat pengetahuan yang kurang terhadap penyakit Tuberculosis paru sebanyak 54 orang (62,1\%). Tingkat upaya pencegahan penularan penyakit TB Paru yang rendah sebanyak 46 orang $(52,9 \%)$ dan ada hubungan yang bermakna antara tingkat pengetahuan dengan upaya pencegahan=penularan Tuberculosis paru di Desa Tanjung Selamat Kecamatan Darussalam Aceh Besar dengan nilai P-value 0,000 .

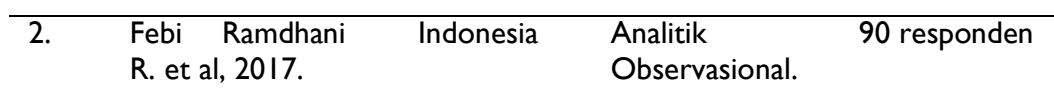

Berdasarkan hasil penelitian menunjukan bahwa mayoritas masyarakat memiliki pengetahuan yang baik 46 Orang $(51,1 \%)$, Sikap yang positif 53 orang $(58,9 \%)$, upaya pencegahan yang cukup 58 orang $(64,4 \%)$. Hasil analisis statistic untuk hubungan pengetahuan, dan sikap terhadap upaya pnecegahan penyakit TB didapatkan nilai $P$ berturut turut adalah hubungan $(p=0,232)$ dan Sikap $(p=0,050)$ dengan mayoritas kelompok pengetahuan yang cukup memiliki upaya pencegahan yang cukup dan kelompok Sikap negatif dengan upaya pencegahan yang cukup. Dapat dartikan bahwa tidak terdapat hubungan bermakna antara pengetahuan dengan upaya pencegahan penyakit TB, dan terdapat hubungan bermakna antara Sikap terhadap upaya pencegahan penyakit TB.

3. Fauzie Rahman Indonesia Cross Sectional. 100 responden
et al, 2017.

Berdasarkan hasil penelitian didapatkan bahwa pengetahuan yang kurang sebanyak 50 responden, responden yang memiliki sikap negative yaitu sebanyak 65 responden, dan yang memiliki upaya pencegahan yang kurang sebanyak 45 responden. Dengan demikian dapat diartikan bahwa ada hubungan antara Pengetahuan $(p=0,000)$ dan Sikap $(p=0,000)$ dengan upaya pencegahan Tuberculosis.

4. Febriani Robeka Indonesia Cross Sectional. 88 responden
Wanma. et al,
2020.

Berdasarkan hasil penelitian diketahui bahwa tingkat pengetahuan responden masih kurang sebanyak 42 (48\%) dan yang memiliki perilaku upaya pencegahan cukup sebanyak 49 (56\%) serta yang memiliki sikap negatif sebanyak 65 (74\%). Hasil uji statistik dengan Spearman rho yaitu nilai $p$ value $=0,2$ I 4 artinya apabila nilai $p<0,05$ berarti tidak ada hubungan korelasi antara tingkat pengetahuan dan perilaku pencegahan Tuberculosi, namun terdapat hubungan korelasi antara sikap dan perilaku pencegahan Tuberculosis dengan nilai $P$ value $=0,000(p<0,05)$ dengan nilai koefisien yang didapat $0,5 \mathrm{I} 4$ yang artinya memiliki kekuatan hubungan antara 2 variabel tersebut kuat.

\begin{tabular}{llll}
\hline 5. Dessy Denila S. Indonesia & Cross Sectional. & 100 responden & Berdasarkan hasil penelitian menunjukan \\
et al, 2017. & & $49 \%$ responden memiliki upaya pencegahan \\
& & penyakit TBC kurang, 50\% responden \\
& & memiliki pengetahuan kurang terhadap upaya \\
& & pencegahan penyakit TBC. Analisis bivariate \\
& & dan uji Chi-square pada $\alpha=0,05$, hasil analisis \\
& & didapatkan ada hubungan antara \\
\hline
\end{tabular}


pengetahuan dengan upaya pencegahan penyakit TBC $P$ value 0,000 dan ada hubungan antara sikap masyarakat dengan upaya pencegahan penyakit TBC $p$ value 0,009 sehingga dapat disimpulkan ada hubungan bermakna pengetahuan dan sikap dengan upaya pencegahan TBC.

\begin{tabular}{llll}
\hline 6. & Mohamad & Indonesia Cross Sectional. 27 responden \\
& Ridwan \\
& Nasirudin et al, \\
& & \\
& &
\end{tabular}

Jasarkan hasil penelitian menunjukan bahwa responden yang berpengetahuan baik dan berperilaku bai sebanayak II orang $(61,1 \%)$ dan responden yang berpengetahuan buruk dan berperilaku buruk sebanyak 5 orang (55,6\%). Hasil uji statistik didapatkan nilai Fisher's Exact Test $\mathrm{P}=0,44>\alpha=0,05$ yang berarti tidak ada hubungan antara tingkat pengetahuan dengan perilkaku pencegahan penularan TB. Responden yang mempunyai perilaku bauk dan sikap yang baik sebanyak 9 $(52,9 \%)$ dan perilaku buruk dengan sikap yang buruk sebanyak 4 orang $(40 \%)$ nilai Fisher's Exact Tes $\mathrm{p}=0,1000>\alpha=0,05$ yang berarti tidak ada hubungan antara sikap tentang TB dengan perilaku pencegahan TB diwilayah Kerja Puskesmas Ngemplak Kabupaten Boyolali.

\section{PEMBAHASAN}

Hasil dari pencarian literature telah ditemukan 6 jurnal yang terkait dengan hubungan tingkat pengetahuan dengan sikap masyarakat tentang upaya pencegahan penularan Tuberculosis. Dari ke 6 jurnal tersebut, terdapat 3 jurnal yang menyatakan terdapat hubungan antara pengetahuan dengan sikap masyarakat tentang upaya pencegahan penularan Tuberculosis, sedangkan 3 jurnal menyatakan tidak ada hubungan antara pengetahuan dengan upaya pencegahan Tuberculosi. Hal ini dengan didukungnya penelitian pertama oleh penelitian Offi Miranda dkk (2019) yang dilaksanakan di Desa Tanjung Selamat Kecamatan Darussalam Aceh Besar, dengan metode survey melalui pendekatan cross sectional yang meneliti hubungan tingkatan pengetahuan dengan upaya pencegahan penularan Tb paru, analisis data menggunkan uji Chi Square. Hasil penelitian menyebutkan ada hubungan antara tingkat pengetahuan dengan upaya pencegahan TB Paru ( $P$ value $=0,000)$, tingkat pengetahuan yang kurang terhadap penyakit TB Paru sebesar 62,1\% dan upaya pencegahan penularan penyakit TB Paru yang rendah sebesar $52,9 \%$. Penelitian menyatakan bahwa mayoritas responden ada 10 (100\%) responden yang memiliki pengetahuan baik, terdapat $8(80,0 \%)$ orang memiliki upaya pencegahan yang tinggi dan 2 (20,0\%) orang memiliki upaya pencegahan yang rendah. 23 (100\%) responden yang memiliki pengetahuan cukup, terdapat I8 (78,3\%) orang yang memiliki upaya pencegahan tinggi dan $5(21,7 \%)$ orang memiliki upaya pencegahan yang rendah. Serta dari 54 (100\%) responden yang memiliki pengetahuan kurang, terdapat 15 (27,6\%) orang yang memiliki upaya pencegahan tinggi dan 39 $(72,2 \%)$ orang yang memiliki upaya pencegahan rendah. Penelitian kedua oleh Febi Ramdhani Rachman dkk (2017) juga menyatakan bahwa berdasarkan uji Spearman Correlation Test nilai $p=0,050(\leq 0,05)$ yang berarti secara statistic ada hubungan yang signifikan antara Sikap dengan upaya pencegahan Tb paru di RW 03 di kelurahan Dunguscariang kota Bandung Tahun 2017. Diketahui bahwa Mayoritas responden memiliki sikap yang negatif dengan upaya pencegahan penyakit TB yang cukup sebanyak 24 orang $(64,9 \%)$ lebih tinggi dibandingkan sikap yang positif dengan upaya pencegahan penyakit TB yang cukup sebanyak 34 orang (64,2\%). Penelitian ketiga Fauzie Rahman dkk (20I7) Hasil penelitian menggunakan uji chi square menunjukkan ada hubungan antara pengetahuan $(p=0,000)$ dan sikap $(p=0,000)$, dapat disimpulkan bahwa ada hubungan pengetahuan dan sikap dengan 
upaya pencegahan tuberkulosis. Diketahui bahwa mayoritas responden ada 20 yang memiliki pengetahuan baik, 15 responden $(75 \%)$ diantaranya memiliki upaya pencegahan Tuberkulosis yang baik, dari 30 responden yang memiliki pengetahuan cukup, 27 responden $(55,9 \%)$ diantaranya memiliki upaya pencegahan Tuberkulosis yang cukup dan dari 50 responden yang memiliki pengetahuan kurang, 4I responden (82\%) memiliki upaya pencegahan tuberkulosis yang kurang. Penelitian ke empat oleh Penelitian Febriani Robeka Wanma dkk (2020) yang dilaksanakan di Distrik Meyado, Kabupaten Teluk Bintuni, Papua Barat, analisis data menggunkan uji Spearman rho. Hasil penelitian menyebutkan $p=$ value $0.214(p=<0,05)$ yang berarti tidak ada hubungan antara pengetahuan dengan perilaku upaya pencegahan Tb Paru, $P$ value $=0,00 \quad(p<0,05)$ yang berarti ada hubungan antara sikap dengan perilaku upaya pencegahan Tb Paru. Diketahui bahwa mayoritas responden sebanyak 23 orang $(26,1 \%)$ yang terdiri dari 4 orang (4,5\%) dengan perilaku pencegahan baik, 12 orang (13,6\%) dengan perilaku pencegahan cukup, dan 7 orang (8,0\%) memiliki perilaku pencegahan kurang. Responden dengan tingkat pengetahuan cukup sebanyak 31 orang $(35,2 \%)$ yang terdiri dari 5 orang (5,7\%) dengan perilaku pencegahan baik, 15 orang (I7\%) dengan perilaku pencegahan yang cukup dan II orang (12,5\%) dengan perilaku pencegahan yang kurang. Responden dengan tingkat pengetahuan kurang sebanyak 38 orang $(36,6 \%)$ yang terdiri dari 5 orang $(5,7 \%)$ dengan perilaku pencegahan baik, 22 orang (25,0\%) dengan perilaku pencegahan cukup serta 7 orang $(25 \%)$ dengan perilaku pencegahan yang kurang. Hasil penelitian ini sejalan dengan penelitian yang dilakukan oleh (Rahman et al., 2017) dengan tingkat pengetahuan kurang sebanyak 50 (50\%) responden. Dalam teori, pengetahuan atau kognitif merupakan domain yang sangat penting untuk terbentuknya tindakan seseorang. Pengetahuan manusia secara keseluruhan didapatkan oleh mata dan telinga. Faktor- faktor yang mempengaruhi pengetahuan seseorang yaitu umur, pengalaman, pendidikan, pekerjaan, informasi, lingkungan dan social budaya. Penelitian ke lima oleh Dessy Denila Sari dkk (2017) di Kelurahan Pulogadung Jakarta Timur Tahun 2016, Hasil penelitian menggunakan uji chi square menunjukkan ada hubungan antara pengetahuan $(p=0,000)$ dan sikap $(p=0,009)$, dapat disimpulkan bahwa ada hubungan pengetahuan dan sikap dengan upaya pencegahan tuberkulosis. Diketahui bahwa mayoritas responden ditemukan sebanyak 49 orang (49\%) responden memiliki upaya pencegahan yang "kurang", dan 5I orang (5I\%) memiliki upaya pengetahuan "baik”. Dan penelitian ke enam oleh Mohamad Ridwan Nasirudin (2017) Di Wilayah Kerja Puskesmas Ngemplak Kabupaten Boyolali, menggunakan uji Hasil uji statistik didapatkan nilai Fisher's Exact Test $\mathrm{P}=0,44>\alpha=0,05$ yang berarti tidak ada hubungan antara tingkat pengetahuan dengan perilkaku pencegahan penularan TB. Nilai Fisher's Exact Tes $p=0,1000>\alpha=0,05$ yang berarti tidak ada hubungan antara sikap tentang TB dengan perilaku pencegahan TB diwilayah Kerja Puskesmas Ngemplak Kabupaten Boyolali. Yang menyatakan tidak ada hubungan yang signifikan antara pengetahuan dengan sikap dalam upaya pencegaan penularan Tb Paru, yang menyatakan bahwa mayoritas responden mempunyai tingkat pengetahuan baik sebanyak 18 orang $(66,7 \%)$ dan responden yang berpengetahuan buruk dan berperilaku yang buruk mendapatkan hasil sebanyak 9 responden (33,3\%).

Tuberkulosis (TB) merupakan salah satu penyakit infeksi menular, yang disebabkan oleh kuman Mycobacterium Tuberculosis. Tuberkulosis saat ini masih merupakan masalah kesehatan masyarakat dunia yang menjadi tantangan global (Direktorat Jenderal Pengendalian Penyakit dan Petunjuk Penyehatan Lingkungan, 2017). Salah satu penyebab kurangnya pengetahuan masyarakat dalam upaya pencegahan penularan penyakit Tuberculosis adalah kurangnya informasi serta edukasi dari tenaga kesehatan atau 
kader-kader posyandu tentang Tuberculosis sehingga menyebabkan kurangnya pengetahuan masyarakat mengenai penyakit Tuberculosi, Serta rendahnya kunjungan masyarakat ke Posyandu dan Puskesmas untuk memeriksakan diri atau deteksi dini terkait penyakit Tuberculosis. Selain itu faktor pengetahuan dan sikap mempunyai pengaruh besar terhadap status kesehatan individu maupun masyarakat dan berperan penting dalam menentukan keberhasilan suatu program penanggulangan penyakit dan pencegahan penularannya termasuk penyakit Tuberkulosis. Pengetahuan merupakan segala sesuatu hal yang dialami dan ditangkap melalui panca indra. Kurangnya pengetahuan masyarakat dapat menyebabkan kurang kepedulian terhadap dampak yang di timbulkan oleh penyakit Tuberculosis. Jika dibiarkan akan memberikan dampak buruk yaitu penularan Tuberculosis akan semakin meluas dan angka kesakitan akibat Tuberculosis akan terus meningkat yang mengakibatkan angka kematian akan terus bertambah, masyarakat yang memiliki pengetahuan yang baik memiliki tindakan pencegahan Tuberculosis Paru lebih baik dibandingkan responden dengan pengetahuan yang rendah (Ridwan, 2019). Namun, sikap juga dapat terbentuk hanya karena meniru orang lain, misalnya saja seseorang hanya bersikap positif dalam hal mencegah Tuberkulosis karena meniru orang tuanya. Masyarakat yang memiliki sikap kurang tetapi memiliki upaya pencegahan Tuberkulosis baik disebabkan adanya keinginan atau rasa takut tertular penyakit Tuberkulosis namun memiliki pengetahuan yang kurang sehingga mereka tidak mengetahui bahwa yang dilakukan dapat menyebabkan penularan Tuberkulosis. Penderita Tuberkulosis paru harus menjaga kontak terhadap keluarganya yang sehat yaitu mengurangi kontak dengan keluarga lainnya untuk sementara selama pengobatan terutama kelompok yang rentan terhadap penularan yaitu bayi dan lansia.

Berdasarkan hasil identifikasi antara fakta dan teori tidak ada kesenjangan dengan hasil penelitian terdapat kesesuaian serta dari 6 jurnal tersebut terdapat 3 dimana menurut Offi Miranda dkk (2019), Fauzie Rahman dkk (2017) dan Dessy Denilla dkk (2017) menyatakan bahwa terdapat hubungan antara pengetahuan dengan sikap masyarakat tentang upaya pencegahan penularan Tuberculosis, sedangkan 3 jurnal menyatakan tidak ada hubungan antara pengetahuan dengan upaya pencegahan Tuberculosis. Dari ke 3 jurnal memiliki kesamaan yaitu pengetahuan, sikap dan upaya pencegahan penularan Tuberculosis Pengetahuan dan Sikap sangat berperan penting dalam mengatasi masalah Tuberculosis di masyarakat. Semakin tinggi pengetahuan seseorang maka akan semakin baik pula orang tersebut dalam Bersikap dan bertindak dalam menangani upaya pencegahan Tuberculosis. Pengetahuan tentang upaya pencegahan Tuberculosis yang baik diharapkan dapat mengurasi risiko penularan Tuberculosis dengan begitu dapat meningkatkan derajat kesehatan masyarakat yang lebih tinggi. Sedangkan 3 jurnal menyatakan tidak ada hubungan antara pengetahuan dengan upaya pencegahan Tuberculosis hal ini dikarenakan pengetahuan masyarakat yang baik belum tentu berhubungan dengan upaya pencegahan Tb Paru yang baik karena kurangnya mengaplikasikan pengetahuan yang dimiliki dalam kehidupan sehari-hari. Sehingga Pengetahuan yang mereka miliki tidak dapat begitu saja diterapkan dalam kehidpan sehari-hari karena adanya pengaruh dari sosial media, keluarga dan lingkungan.

\section{KESIMPULAN}

Berdasarkan hasil penelitian dengan metode literatur review tentang fokus tujuan dari penelitian yaitu untuk mengetahui Hubungan Tingkat pengetahuan dengan sikap masyarakat tentang upaya pencegahan penularan Tuberculosis Paru disimpulkan bahwa Pengetahuan dan Sikap merupakan penunjang dalam melakukan upaya pencegahan penularan Tuberculosis, Pengetahuan dan Sikap seseorang tentang penyakit Tuberkulosis dan 
pencegahan penularannya memegang peranan penting dalam keberhasilan upaya pencegahan penularan penyakit Tuberkulosis. Pendidikan memengaruhi pengetahuan karena semakin tinggi pendidikan seseorang semakin mudah untuk menerima informasi dan dapat diterapkan dalam kehidupan sehari-hari di dalam masyarakat. Masyarakat yang berpendidikan tinggi lebih mudah menerima suatu informasi dibandingkan masyarakat yang berpendidikan rendah, sehingga informasi lebih mudah dapat diterima dan dilaksanakan, pengetahuan yang baik semakin meningkatnya pengetahuan masyarakat tentang upaya pencegahan penularan Tuberculosis di masyarakat dengan memberikan dukungan dan motivasi serta sering membawa anggota keluarga yang terkena penyakit Tuberculosis ke pelayanan kesehatan.

\section{UCAPAN TERIMA KASIH}

Penulis sadar banyak hambatan dalam proses penyusunan laporan penelitian ini, dikarenakan keterbatasan kemampuan penulis sendiri. Oleh Karena itu penulis sampaikan banyak terimakasih kepada semua pihak yang telah memberikan bantuannya, utamanya kepada yang terhormat:

I. Kepala Dinas Kesehatan Kota Palangka Raya

2. Ketua STIKes Eka Harap

3. Rekan-rekan Dosen dan Mahasiswa Prodi Sarjana Kesehatan Masyarakat STIKES Eka Harap

\section{REFERENSI}

I. Departemen Kesehatan RI. (20I4). Pedoman Nasional Pengendakian Tuberculosis. Kementrian Kesehatan RI Direktorat Jenderal Pengendalian Penyakit dan Penyehatan Lingkungan. 2014.

2. Liam Donaldson. (2017). WHO | Healthier, fairer, safer: the global health journey 2007-2017. In Who.

3. Direktorat Jenderal Pengendalian Penyakit dan Petunjuk Penyehatan Lingkungan. (2017). Penemuan Pasien Tuberkulosis. In Kementrian Kesehatan Republik Indonesia.
4. Dinas Kesehatan Kota Palangkaraya. (2020). Profil Kesehatan Kota Palangkaraya Tahun 2019. Persepsi Masyarakat Terhadap Perawatan Ortodontik Yang Dilakukan Oleh Pihak Non Profesional, 53(9), I6891699.

5. Samingan, S. \&. (2017). hubungan Tingkat Pengetahuan dan Sikap Masyarakat Terhadap Upaya Pencegahan tb. Journal of Chemical Information and Modeling, 10(2), 619-624.

6. Ramdhani, D. Y., \& Purba, E. S. (20I8). Hubungan Pengetahuan Dan Sikap Pasien Dengan Upaya Pencegahan Penularan Tuberkulosis Paru Di Wilayah Kerja Puskesmas Muaro Kumpeh Kabupaten Muaro Jambi Tahun 2015. Jurnal Akademika Baiturrahim Jambi, 5(2), 79-88.

7. Rahman, F., Yulidasari, F., Laily, N., \& Rosadi, D. (2017). Pengetahuan dan Sikap Masyarakat Tentang Upaya Pencegahan Tuberculosis. Jurnal MKMI, I3(2), I83-I89.

8. Miranda, Offi dan Ridwan, A. (2019). Hubungan Tingkatan Pengetahuan dengan Upaya Pencegahan Penularan TB Paru. lurnal Ilmiah Mahasiswa Fakultas Keperawatan, 4(2).

9. Denila, D., \& Samingan, S. (2017). Hubungan tingkat pengetahuan dan sikap masyarakat terhadap upaya pencegahan penyakit Tuberkulosis di Kelurahan Pulogadung lakarta Timur Tahun 20I6. Jurnal Bidang Ilmu Kesehatan, 7(2), 22.

10. Nasirudin, M. R. (20I7). Hubungan Tingkat Pengetahuan Dan Sikap Perilaku Pencegahan Penularan Tuberkulosis (TB) Di Wilayah Kerja Puskesmas Ngamplak Kabupaten Boyolali. Junral Program Studi Kesehatan Masyarakat Fakultas IImu Kesehatan Universitas Muhammadiyah Surakarta.

II. Rachman, F. R., Husin, U. A., \& Trisnadi, S. (2019). Hubungan Tingkat Pengetahuan dan Sikap Masyarakat terhadap Upaya Pencegahan Penyakit Tuberkulosis (Studi di RW 03 Kelurahan Dunguscariang Kota Bandung Tahun 2017).

12. Wanma, F. R., Putra, K. P., \& Nusawakan, A. W. (2020). Hubungan Tingkat Pengetahuan, Sikap dan Perilaku Pencegahan Tuberculosis di Distrik Meyado, Kabupaten Teluk Bintuni, Papua Barat.

13. Ridwan, A. (2019). Hubungan Tingkatan Pengetahuan dengan Upaya Pencegahan Penularan TB PARU. JIM FKep, IV(2), 42-47. 